\title{
Erratum to: The Metagenomics and Metadesign of the Subways and Urban Biomes (MetaSUB) International Consortium Inaugural Meeting Report
}

The MetaSUB International Consortium

\section{Erratum}

During pre-publication proofs, some final changes were not included in the manuscript and we also had several sites that joined right before the global city sampling day (CSD) that should be included. These have now been updated in the original paper [1] and the updates are listed below:

1) Rename the section "MetaSUB City Principal Investigators" to "MetaSUB Consortium Members"

The following names should be included:

- Ken McGrath and Leanne McGrath (Brisbane, Australia)

- Andrew Gray (Melbourne, Australia)

- Olayinka Osuolale (Ilorin, Nigeria)

- Nicola Segata (Trenton, Italy)

- Silvia Fillo (Rome, Italy)

- Gregorio Iraola (Montevideo, Uruguay)

- Yiming Zhou (Beijing, China)

- Yujun Chang (Beijing, China)

- Yang Li (Beijing, China)

- Yuanting Zhend (Shanghai, China)
- Wanwan Hou (Shanghai, China)

- Adan Ramirez (Bogota, Colombia)

- Martha Cepeda (Bogota, Colombia)

- Christelle Desnues (Marseille, France)

- Nicolas Rascovan (Marseille, France)

- Amged Ouf (Cairo, Egypt)

- Colin Baron (Düsseldorf, Germany)

- Niranjan Nagarajan (Singapore)

- Danilo Ercolini (Naples, Italy)

- Wayne Menary (Lima, Peru)

- Scott Tighe (Vermont, USA)

- Mohamed Donia (Princeton, USA)

- Shawn Levy (Huntsville, USA)

- Joseph Benito (Huntsville, USA)

- Angela Jones (Huntsville, USA)

2) In the section "The following authors contributed to this manuscript," the following name should be added:

- George Yeh, Millipore Sigma

3) Some of the affiliations in the published version of Table 2 were inaccurate. Please see the corrections below:

* Correspondence: chm2042@med.cornell.edu

Department of Physiology and Biophysics, Weill Cornell Medicine, New York, NY 10021, USA

(c) 2016 The Author(s). Open Access This article is distributed under the terms of the Creative Commons Attribution 4.0 International License (http://creativecommons.org/licenses/by/4.0/), which permits unrestricted use, distribution, and reproduction in any medium, provided you give appropriate credit to the original author(s) and the source, provide a link to the Creative Commons license, and indicate if changes were made. The Creative Commons Public Domain Dedication waiver (http://creativecommons.org/publicdomain/zero/1.0/) applies to the data made available in this article, unless otherwise stated. 


\begin{tabular}{|c|c|c|c|c|c|c|}
\hline Site & City & Country & Department & University/institute & Contact PIs & Email \\
\hline 9 & Guangzhou & China & $\begin{array}{l}\text { 1. Zhongshan ophthalmic } \\
\text { Center, Center for Precision } \\
\text { Medicine; } 2 \text {. Department } \\
\text { of Environmental Health; } \\
\text { 3. Division of Laboratory } \\
\text { Medicine at Zhujiang } \\
\text { Hospital }\end{array}$ & $\begin{array}{l}\text { 1. Sun Yat-sen University; } \\
\text { 2.Southern Medical } \\
\text { University }\end{array}$ & $\begin{array}{l}\text { Zhi Xie1,1/Daisy } \\
\text { Zheng2,2/Hongwei } \\
\text { Zhou2,3 }\end{array}$ & $\begin{array}{l}\text { xiezhi@gmail.com/ } \\
\text { 180553957@qq.com/ } \\
\text { 811807859@qq.com }\end{array}$ \\
\hline 25 & $\begin{array}{l}\text { Auckland, } \\
\text { Hamilton } \\
\text { and Rotorua }\end{array}$ & New Zealand & $\begin{array}{l}\text { Environmental Research } \\
\text { Institute }\end{array}$ & Univeristy of Waikato & $\begin{array}{l}\text { Ayokunle } \\
\text { Christopher Dada }\end{array}$ & cdada@waikato.ac.nz \\
\hline 33 & Johannesburg & South Africa & Data Driven Healthcare & IBM Research-Africa & Geoffrey H Siwo & gsiwo@za.ibm.com \\
\hline 40 & Montevideo & Uruguay & Informatik & ETH Zurich & Gaston Gonnet & gonnet@ethz.ch \\
\hline 47 & Sacramento & USA & $\begin{array}{l}\text { Department of Ecology } \\
\text { and Evolution }\end{array}$ & UC Davis & Jonathan Eisen & jonathan.eisen@gmail.com \\
\hline
\end{tabular}

4) The following errors in the manuscript should be corrected:

a. In "Website Curator" Sofia Ahsanuddin's name is incorrectly spelled as Ahsannudin

b. PAGE 3: Table 1 row 2, Surface composition category, the word "metal" was repeated twice.

c. For Ayokunle Christopher Dada's affiliation, Auckland City should be Auckland, Hamilton and Rotorua (New Zealand).

d. In the "Inaugural MetaSUB International Meeting Speakers" section, Russel Neches should be "Russell Neches"

e. In the section DNA extraction, Proteinase $\mathrm{K}$ is not in the Polyzyme mixture and therefore the sentence should read: 'Currently, members of the consortium are testing a newenzyme cocktail for DNA extraction consisting of lysozyme,mutanolysin, achromopeptidase, lysostaphin, chitinase, and lyticase'.

f. Elena M. Vayndorf is the correct full name for Dr. Vayndorf.

g. The legend of Figure 1 should read, "Compliments of the ABRF Metagenomics Research Group"

h. Table 2 heading should change from "Contact pis" to "Contact PIs"

i. Emails for PIs of Doha are a.chatziefthimiou@richenvironments.com/ salama.b.chaker@gmail.com

j. Dr. Niyaz Ahmed should be removed from the "MetaSUB Consortium Members" list.

5) Acknowledgements

a. This work was also supported in part by the National High Technology Research and Development Program of China (2015AA020104), the National Natural Science Foundation of China (31471239) and the 111 Project (B13016).
Received: 29 June 2016 Accepted: 29 June 2016

Published online: 18 August 2016

Reference

1. The MetaSUB International Consortium. The Metagenomics and Metadesign of the Subways and Urban Biomes (MetaSUB) International Consortium inaugural meeting report. Microbiome. 2016;4:24.

Submit your next manuscript to BioMed Central and we will help you at every step:

- We accept pre-submission inquiries

- Our selector tool helps you to find the most relevant journal

- We provide round the clock customer support

- Convenient online submission

- Thorough peer review

- Inclusion in PubMed and all major indexing services

- Maximum visibility for your research

Submit your manuscript at www.biomedcentral.com/submit 